\title{
Diversity of the euglossine bee community (Hymenoptera, Apidae) of an Atlantic Forest remnant in southeastern Brazil
}

\author{
Guilherme do Carmo Silveira ${ }^{1}$, Anderson Machado Nascimento², \\ Silvia Helena Sofia $^{3} \&$ Solange Cristina Augusto ${ }^{1}$
}

\begin{abstract}
'Laboratório de Ecologia e Comportamento de Abelhas, Universidade Federal de Uberlândia, Campus Umuarama, Bloco 2D, 38400-902 UberlândiaMG, Brasil. guisilve@yahoo.com.br; scaugusto@umuarama.ufu.br

${ }^{2}$ Departamento de Ciências Biológicas, Universidade de Franca, Parque Universitário, Caixa Postal 82, 14404-600 Franca-SP, Brasil. morenascimento@yahoo.com.br

${ }^{3}$ Laboratório de Genética e Ecologia Animal, Departamento de Biologia Geral, Universidade Estadual de Londrina, CP 6001, 86051-990 Londrina-PR, Brasil.shsofia@uel.br
\end{abstract}

\begin{abstract}
Diversity of the euglossine bee community (Hymenoptera, Apidae) of an Atlantic Forest remnant in southeastern Brazil. Euglossine bees, attracted to scent baits of cineole, eugenol and vanillin, were collected with entomological nets, from December 1998 to November 1999. Samplings were carried out once a month simultaneously by two collectors positioned in two different sites in an Atlantic Forest remnant in northeastern São Paulo state, Brazil. A total of 859 male euglossine bees, belonging to 13 species and four Euglossini genera were collected. Of the total sample, 506 (12 species) males were captured at site A and 353 (10 species) were collected at site B. In both sites, Euglossa pleosticta Dressler, 1982 was the most abundant species (45.79\%), followed by Eulaema nigrita Lepeletier, 1841 (20.79\%). The results of this study supply new information about the diversity of orchid bee fauna in Atlantic Forest remnants as well as show that more than one site is needed to sample these bees in a fragmented landascape.
\end{abstract}

KEYWORDS. Neotropical insects; orchid bees; semidecidual seasonal forest.

\begin{abstract}
RESUMO. Diversidade de abelhas Euglossini (Hymenoptera, Apidae) em um remanescente de Floresta Atlântica no sudeste do Brasil. Abelhas Euglossini, atraídas às iscas odoríferas de cineol, eugenol e vanilina foram coletadas com rede entomológica durante os meses de dezembro de 1998 a novembro de 1999, em um remanescente de Floresta Atlântica localizado no nordeste do estado de São Paulo, Brasil. As amostragens foram realizadas, uma vez ao mês, simultaneamente por dois coletores posicionados em dois pontos distintos na área de estudo. No total, 859 machos pertencentes a 13 espécies e quatro gêneros foram coletados em ambos os sítios. Do total de abelhas amostradas, 506 (12 espécies) foram capturadas no sítio A e 353 (10 espécies) no sítio B. Em ambos os sítios, Euglossa pleosticta Dressler, 1982 foi a espécie mais abundante (45,79\%), seguida por Eulaema nigrita Lepeletier, $1841(20,79 \%)$. Os resultados deste estudo fornecem informações adicionais sobre a diversidade das abelhas das orquídeas em remanescentes de Floresta Atlântica, bem como mostram que mais de um ponto de amostragem se faz necessário para se obter informações mais precisas sobre as comunidades de Euglossini em paisagens fragmentadas.
\end{abstract}

PALAVRAS-CHAVE. Abelhas das orquídeas; floresta estacional semidecidual; insetos neotropicais.

Neotropical euglossine or orchid bees (Hymenoptera, Apidae, Euglossini) have been the focus of numerous investigations over the last four decades since Dodson et al. (1969) showed that the males could be surveyed by means of chemical attractants. The findings of these studies contributed profoundly to the understanding of euglossine fauna distributed throughout the Neotropical region. Currently, around 200 species of Euglossini bees are known, although new species have been continually described in surveys carried out across Tropical America (Ramírez 2005; Anjos-da-Silva \& Rebêlo 2006; Parra-H \& Nates-Parra 2007; Nemésio 2006, 2007a, 2009), indicating that further studies are still necessary.

Although the majority of Euglossini diversity occurs in low latitudes (Rebêlo 2001; Roubik \& Hanson 2004), especially in the Amazonian Forest (Nemésio \& Silveira 2007a), euglossine bees are widely distributed throughout the Atlan- tic Forest, occurring in a variety of ecosystems in this severely threatened biome (Peruquetti et al. 1999; Nemésio \& Silveira 2007a). Two recent studies have listed 51 Euglossini species in the Atlantic Forest, 26 of which are considered endemic to this biome (Nemésio \& Silveira 2007b; Nemésio 2009). However, according to Nemésio (2009), few areas have been extensively sampled for orchid bee fauna in the Atlantic Forest. This is especially true in southeastern Brazil, where euglossine bees from Atlantic Forest remnants have been surveyed only in a limited number of studies carried out in the states of São Paulo (Rebêlo \& Garófalo 1991, 1997; Garófalo et al. 1998), Minas Gerais (Nemésio 2003; Nemésio \& Silveira 2006, 2007a), Rio de Janeiro (Tonhasca et al. 2002a; Aguiar \& Gaglianone 2008; Ramalho et al. 2009) and Espírito Santo (Bonilla-Gómez 1999). In all these studies chemical baits were used to acquire information about Euglossini communities occurring in Atlantic Forest ecosystems. 
After centuries of deforestation, nowadays most of the remaining Atlantic Forest exists as small (more than $80 \%$ of remaining fragments are $<50$ ha) and isolated forest fragments (Ribeiro et al. 2009), which probably represent the final reserves of local biodiversity in many regions. Furthermore, according to these authors, almost half the forest remnants are less than $100 \mathrm{~m}$ distant from their edges, which subjects the remaining forest to strong edge-effect influences. These conditions of Atlantic Forest remnants expose the forest's biodiversity to risk of extintion (Ribeiro et al. op.cit.). Thus, more efforts are needed to acquire a better knowledge of the biodiversity of these remnants before conservation actions can be implemented in different areas.

Another question that has received little attention in studies involving euglossine communities is whether a single sampling site is sufficient to suitably characterize the diversity of local euglossine fauna. Some reports have shown that both euglossine richness and/or abundance can vary over short distances (Becker et al. 1991, Ambruster 1993), 'making it difficult to characterize a forest by sampling a single site' (Becker et al. 1991).

In this context, the current study presents information about the euglossine community from a well-preserved Brazilian Atlantic Forest remnant in southeastern Brazil as well as shows the importance of taking simultaneous samples from more than one sampling site in a fragmented landscape.

\section{MATERIAL AND METHODS}

Study area. This study was carried out in an Atlantic Forest remnant located on private property (Santa Cecília Farm: $\mathrm{SCF})$, in the municipality of Patrocínio Paulista (2046' 12 "S, $47^{\circ} 14$ '24'W), located in northeast São Paulo state. The study area was a semideciduous seasonal forest fragment of 49 ha surrounded by cultivated land, pasture and "Cerrado" (the typical Brazilian savannah) totalling 96 ha, with altitudes ranging from 800 to $1040 \mathrm{~m}$. The area contains very wellpreserved native vegetation including many species of native trees, such as: Ficus guaranitica Chodat \& Vischer, Cariniana estrellensis (Raddi) Kuntze, Cariniana legalis (Mart.) O. Ktze., Gallesia integrifolia (Spreng.) Harms, Aspidosperma polyneuron (Müll.) Arg. and Euterpe edulis Martius as well as a variety of orchids and bromeliads (Gazola 2006).

The local climate is classified as Awb (Köppen) with two defined seasons, a cool dry season from April to September, with monthly temperature and precipitation means ranging from 17.4 to $22.3^{\circ} \mathrm{C}$ and 0.2 to $122.9 \mathrm{~mm}$, respectively, and a hot wet season from October to March, with monthly temperature and precipitation ranging from 21.1 to $23.3^{\circ} \mathrm{C}$ and 29.3 to $363.8 \mathrm{~mm}$, respectively (Gazola \& Garófalo 2009).

Samplings. Male euglossine bees were sampled simultaneously by two collectors positioned at two different sites ( sites A and B) in the studied area. Although the use of insect nets was a factor that limited the number of survey sites in the present study, the choice for using this method was based on its higher efficacy than bait traps, which usually show low capture efficiency (Nemésio \& Morato 2006). Both sampling sites were located on the border of the forest fragment about $1000 \mathrm{~m}$ apart on opposite sides. However, it should also be mentioned that site B (SB) was positioned near the transition between the forest fragment and an area of Cerrado (tropical savannah), which were separated by only $100 \mathrm{~m}$. Air temperature and relative humidity were measured every hour at each sampling site during the collections using a hygrometer with dry and wet bulbs hung $1.2 \mathrm{~m}$ above the soil surface.

Bees were collected one a month from December 1998 to November 1999. Samplings were carried out simultaneously in both sites, from 9:00 to 11:00 a.m. This interval is considered satisfatory to sample euglossine bees because a higher number of male visits in the region have been observed (Rebêlo \& Garófalo 1991, 1997). To make the census more effective, clear days were chosen whenever possible (Janzen et al. 1982). The baits were placed in the shade, hanging from branches at about $1.5 \mathrm{~m}$ above ground and approximately $10 \mathrm{~m}$ apart. Three aromatic compounds were used (cineole, eugenol and vanillin), which were replenished every hour in order to maintain a high and homogeneous attractiveness (Uehara-Prado \& Garófalo 2006). These aromatic baits are the most commonly employed chemicals for studies involving these bees in northeastern São Paulo state (Rebêlo \& Garófalo 1991, 1997; Garófalo et al. 1998).

Bees attracted to baits were captured with entomological nets and killed with ethyl acetate. They were identified in the laboratory, labeled and then deposited in the entomological collection of the Laboratory of Ecology and Behavior of Bees of the Universidade Federal de Uberlândia.

Data analysis. The $\mathrm{G}$ test was used to verify if the difference in orchid bee abundance between the two sites was significant.

To estimate and compare the sampling efficiency of euglossine bee fauna, species accumulation curves (cumulative number of species collected against a measure of the sampling effort) were constructed (100 runs) for the data set from each sampling site (SA and SB) and analyzed both jointly and independently. EstimateS 8.0 software (Cowell 2006) with Ice mean, Chao 1, Jack 1 and Jack 2 non-parametric estimators was used to verify area sampling sufficiency.

Species diversity and evenness were calculated using the indices of Shannon-Wiener (H') and Pielou (J'), respectively (Ludwig \& Reynolds 1988). The frequency of occurrence (OF) and species dominance (D) were calculated according to Palma (1975) apud Buschini (2006): OF = (number of sampling with species $i \div$ number of sampling $) \times 100$. For $\mathrm{OF} \geqslant 50 \%$, the species is considered a primary species $(\mathrm{p})$, which means very frequent; for $50 \% \geqslant \mathrm{OF} \geqslant 25 \%$, the species is considered a secondary species (s) or frequent, and for $25 \% \geqslant \mathrm{OF}$, the species is considered an incidental species (i), or infrequent. $\mathrm{D}=($ Abundance of species $\mathrm{i} \div$ total abundance) $\times 100$. In this case, when $\mathrm{D}>5 \%$ the species was considered a dominant species (d); for $2.5 \%<\mathrm{D}<5 \%$ 
the species was considered an accessory species and for $\mathrm{D}<$ $2.5 \%$ the species was considered an incidental or occasional species (i). When these indices are used together, the species can be characterized as one of three categories $(\mathrm{Ct})$ : common, intermediate or rare.

The percent similarity between euglossine fauna from sites A and B was compared by Renkonen index, which is defined as: $S_{r}=\Sigma \min \left(p_{1 i}, p_{2 i}\right)$, where $p_{\mathrm{i}}$, is the frequency of species $i$ in collection. This measure of sample similarity is considered one of the best quantitative similarity coefficients because it is not heavily influenced by sample size or species number (Wolda 1981).

To compare orchid bee fauna from sites A and B, a pairwise similarity matrix was generated by using the BrayCurtis index (percentage of similarity) applied to the frequency data for the species at each sampling site. For this analysis, the data from each sampling site was analyzed separately by season (warm-wet and cold-dry- the former ranging from October to March and the latter from April to September). A multidimensional scaling (MDS) analysis was carried out on the basis of these similarity matrix-values. This analysis required neither normality nor linearity of data (Kruskal $\&$ Wish 1978), and a stress value was calculated. The smaller the value, the better the fit of the reproduced similarity matrix to the observed similarity matrix (Arroyo-Rodríguez et al. 2008).

Student's t-test was used to compare inter-site temperature. To verify the relation between abundance and temperature in each site, Pearson's correlations were subsequently used.

\section{RESULTS}

A total of 859 male euglossine bees, belonging to 13 species and four Euglossini genera, were collected at the sampling sites in SCF (Table I). Of the total sample, 506 bees ( 12 species) and 353 (10 species) were captured at sites $\mathrm{A}$ and $\mathrm{B}$, respectively. Nine species were common to both sites; Euglossa leucotricha Rebêlo \& Moure, 1996, Eufriesea auriceps (Friese, 1899) and Exaerete smaragdina (Guérin, 1845) were collected only at site A while Exaerete dentata (Linnaeus, 1758) at site B (Table I). This difference in abundance was statistically significant according to the G-Test $(\mathrm{G}-\mathrm{Test}=59.1551 ; \mathrm{p}<0.001)$. Additionaly, the percentage of similariy between the two sites was low (PS $=38.4 \%)$ and the species composition showed little variation between these sites. In both sites, Euglossa pleosticta Dressler, 1982 was the most abundant species (45.79\%), followed by Eulaema nigrita Lepeletier, 1841 (20.79\%). The remaining species together corresponded to $33.42 \%$ of the total.

The three species accumulation curves obtained for the data sets from both sampling sites, analyzed both together and separately, did not reach an asymptote (Fig. 1). The values obtained from applying the non-parametric estimators indicated that only about $65 \%$ of the Euglossini species inhabiting the study area were captured (Fig. 1).

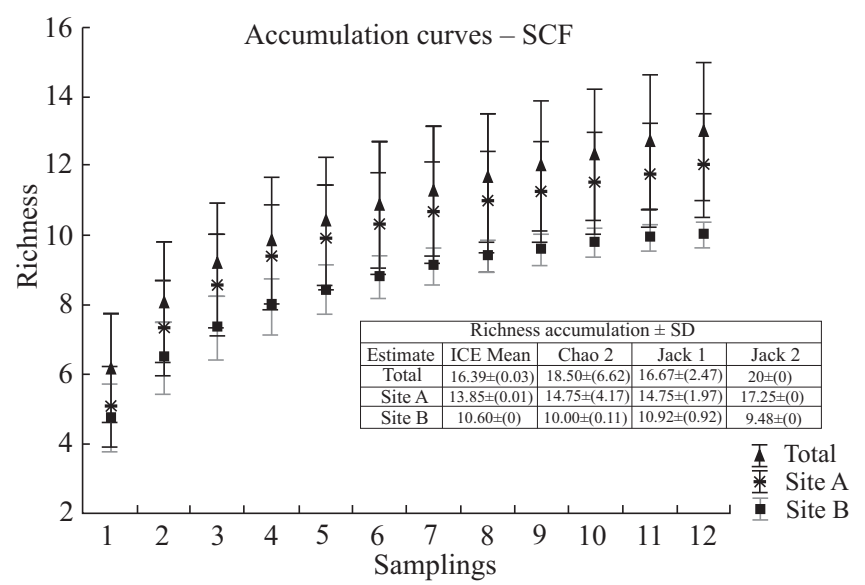

Fig. 1. Species accumulation curve representing the total accumulated number of species of euglossine bees depending on the number of samplings (with standard deviation): for the total area, and for each site separately; $\mathrm{SA}=$ site $\mathrm{A}$ and $\mathrm{SB}=$ site $\mathrm{B}$. Bees were sampled from December 1998 to November 1999. SCF $=$ study area.

The diversity and evenness index for the given area were $\mathrm{H}^{\prime}=1.65$ and $\mathrm{J}^{\prime}=0.65$, respectively. Similar values were found when each site was considered seperately: $\mathrm{H}^{\prime}=1.59$ and $\mathrm{J}^{\prime}=0.63$ (site $\left.\mathrm{A}\right) ; \mathrm{H}^{\prime}=1.67$ and $\mathrm{J}^{\prime}=0.72$ (site B).

The number of sampled males was higher during December, October and November $(54.67 \%$ of total) at site A and higher in December and April (34.84\%) at site B (Fig. 2).

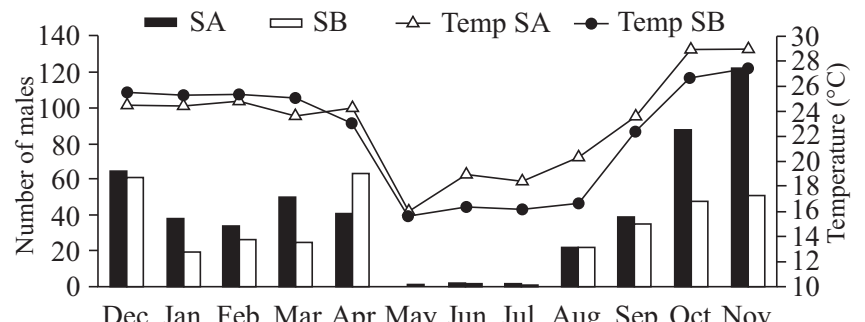

Fig. 2. Mean temperature $\left({ }^{\circ} \mathrm{C}\right)$ at sites $\mathrm{A}(\mathrm{SA})$ and $\mathrm{B}(\mathrm{SB})$ and number of euglossine males collected at each of these sites, between December 1998 and November 1999. Both sites were located in a forest remnant at the Santa Cecília Farm in the municipality of Patrocínio Paulista-SP, southeastern Brazil.

Euglossa pleosticta, Eulaema nigrita, Euglossa stellfeldi Moure, 1947 and Euglossa fimbriata Moure, 1996 were the most abundants and frequent species, and were classified as common species (Table II). Although Eufriesea violacea (Blanchard, 1840) was an abundant species, it was not frequent. Four species were considered rare, none of which were collected at both sites: Eg. leucotricha, Ef. auriceps and the kleptoparasites Exaerete smaragdina and Exaraete dentata (Table II).

In general, cineole was the most efficient fragrance, attracting a total of $358(71.17 \%)$ males at site A and 242 
Table I. Number and percentage of different species of euglossine males collected in sites A and B of a well-preserved semi-deciduous forest remnant of Atlantic Forest in southeastern Brazil, from December 1998 to November 1999.

\begin{tabular}{|c|c|c|c|c|c|c|}
\hline Species & Site A & $\%$ & Site B & $\%$ & Total & $\%$ \\
\hline Euglossa (Euglossa) pleosticta Dressler, 1982 & 260 & 51.38 & 132 & 37.39 & 392 & 45.63 \\
\hline Euglossa (Glossura) stellfeldi Moure, 1947 & 26 & 5.14 & 39 & 11.05 & 65 & 7.57 \\
\hline Euglossa (Euglossa) fimbriata Rebêlo \& Moure, 1996 & 43 & 8.50 & 12 & 3.40 & 55 & 6.40 \\
\hline Euglossa (Glossura) imperialis Cockerell, 1922 & 16 & 3.16 & 21 & 5.95 & 37 & 4.31 \\
\hline Euglossa (Euglossa) truncata Rebêlo \& Moure, 1996 & 14 & 2.77 & 15 & 4.24 & 29 & 3.38 \\
\hline Euglossa (Euglossa) melanotricha Moure, 1967 & 10 & 1.98 & 5 & 1.42 & 15 & 1.75 \\
\hline Euglossa (Euglossa) carolina Nemésio, 2009 & 4 & 0.79 & 2 & 0.57 & 6 & 0.70 \\
\hline Euglossa (Euglossa) leucotricha Rebêlo \& Moure, 1996 & 1 & 0.20 & 0 & 0.00 & 1 & 0.12 \\
\hline Eulaema (Apeulaema) nigrita Lepeletier, 1841 & 78 & 15.42 & 103 & 29.18 & 181 & 21.07 \\
\hline Eufriesea violacea (Blanchard, 1840) & 52 & 10.28 & 23 & 6.52 & 75 & 8.73 \\
\hline Eufriesea auriceps (Friese, 1899) & 1 & 0.20 & 0 & 0.00 & 1 & 0.12 \\
\hline Exaerete smaragdina (Guérin, 1845) & 1 & 0.20 & 0 & 0.00 & 1 & 0.12 \\
\hline Exaerete dentata (Linnaeus, 1758) & 0 & 0.00 & 1 & 0.28 & 1 & 0.12 \\
\hline Number of species sampled & 12 & - & 10 & - & 13 & - \\
\hline Number of individuals & 506 & 100.00 & 353 & 100.00 & 859 & 100.00 \\
\hline Species diversity $\left(\mathrm{H}^{\prime}\right)$ & 1.65 & & 1.59 & & 1.67 & \\
\hline
\end{tabular}

Table II. Species occurrence frequency (OF), dominance (D) and category $(\mathrm{Ct})$ of euglossine bees collected in the studied area: for the total area $(\mathrm{T})$, and for each site separately; $\mathrm{SA}=$ site $\mathrm{A}$ and $\mathrm{SB}=$ site $\mathrm{B}$. Bees were sampled from December 1998 to November 1999.

\begin{tabular}{|c|c|c|c|c|c|c|c|c|c|}
\hline \multirow{2}{*}{ Specie } & \multicolumn{3}{|c|}{$\mathrm{OF}$} & \multicolumn{3}{|c|}{$\mathrm{D}$} & \multicolumn{3}{|c|}{$\mathrm{Ct}$} \\
\hline & $\mathrm{T}$ & SA & SB & $\mathrm{T}$ & SA & SB & $\mathrm{T}$ & SA & SB \\
\hline Euglossa (Euglossa) pleosticta & $\mathrm{p}$ & $\mathrm{p}$ & $\mathrm{p}$ & $\mathrm{D}$ & $\mathrm{D}$ & $\mathrm{d}$ & $\mathrm{C}$ & $\mathrm{C}$ & $\mathrm{C}$ \\
\hline Euglossa (Glossura) stellfeldi & $\mathrm{p}$ & $\mathrm{p}$ & $\mathrm{p}$ & $\mathrm{D}$ & $\mathrm{D}$ & $\mathrm{d}$ & $\mathrm{C}$ & $\mathrm{C}$ & $\mathrm{C}$ \\
\hline Euglossa (Euglossa) fimbriata & $\mathrm{p}$ & $\mathrm{p}$ & $\mathrm{s}$ & $\mathrm{D}$ & $\mathrm{D}$ & $\mathrm{a}$ & $\mathrm{C}$ & $\mathrm{C}$ & I \\
\hline Euglossa (Glossura) imperialis & $\mathrm{p}$ & $\mathrm{i}$ & $\mathrm{p}$ & A & A & $\mathrm{d}$ & I & I & $\mathrm{C}$ \\
\hline Euglossa (Euglossa) truncata & $\mathrm{p}$ & $\mathrm{i}$ & $\mathrm{p}$ & A & A & a & I & I & I \\
\hline Euglossa (Euglossa) melanotricha & $\mathrm{s}$ & $\mathrm{s}$ & $\mathrm{i}$ & I & I & $\mathrm{i}$ & I & I & $\mathrm{R}$ \\
\hline Euglossa (Euglossa) carolina & $\mathrm{s}$ & $\mathrm{S}$ & $\mathrm{i}$ & I & I & $\mathrm{i}$ & I & I & $\mathrm{R}$ \\
\hline Euglossa (Euglossa) leucotricha & $\mathrm{i}$ & $\mathrm{i}$ & - & I & I & - & $\mathrm{R}$ & $\mathrm{R}$ & - \\
\hline Eulaema (Apeulaema) nigrita & $\mathrm{p}$ & $\mathrm{p}$ & $\mathrm{p}$ & $\mathrm{D}$ & $\mathrm{D}$ & $\mathrm{d}$ & $\mathrm{C}$ & $\mathrm{C}$ & $\mathrm{C}$ \\
\hline Eufriesea violacea & $\mathrm{s}$ & $\mathrm{s}$ & $\mathrm{i}$ & $\mathrm{D}$ & $\mathrm{D}$ & $\mathrm{d}$ & I & I & I \\
\hline Eufriesea auriceps & $\mathrm{i}$ & $\mathrm{i}$ & - & I & I & - & $\mathrm{R}$ & $\mathrm{R}$ & - \\
\hline Exaerete smaragdina & $\mathrm{i}$ & $\mathrm{i}$ & - & I & I & - & $\mathrm{R}$ & $\mathrm{R}$ & - \\
\hline Exaerete dentata & $\mathrm{i}$ & - & $\mathrm{i}$ & I & - & $\mathrm{i}$ & $\mathrm{R}$ & - & $\mathrm{R}$ \\
\hline
\end{tabular}

(68.56\%) males at site B (Fig. 3). Vanillin was the second most attractive chemical compound, attracting $18.69 \%$ and $19.84 \%$ of the male visitors collected from sites A and B, respectively. However, it is important to mention that eugenol was equally or even more attractive than cineole for both $\mathrm{Eg}$. truncata Rebêlo \& Moure, 1996 and Eg. stellfeldi (Fig. 3).

The MDS analysis (stress value $<0.0001$ ) revealed seasonal differences among orchid bee fauna at both sites (Fig.
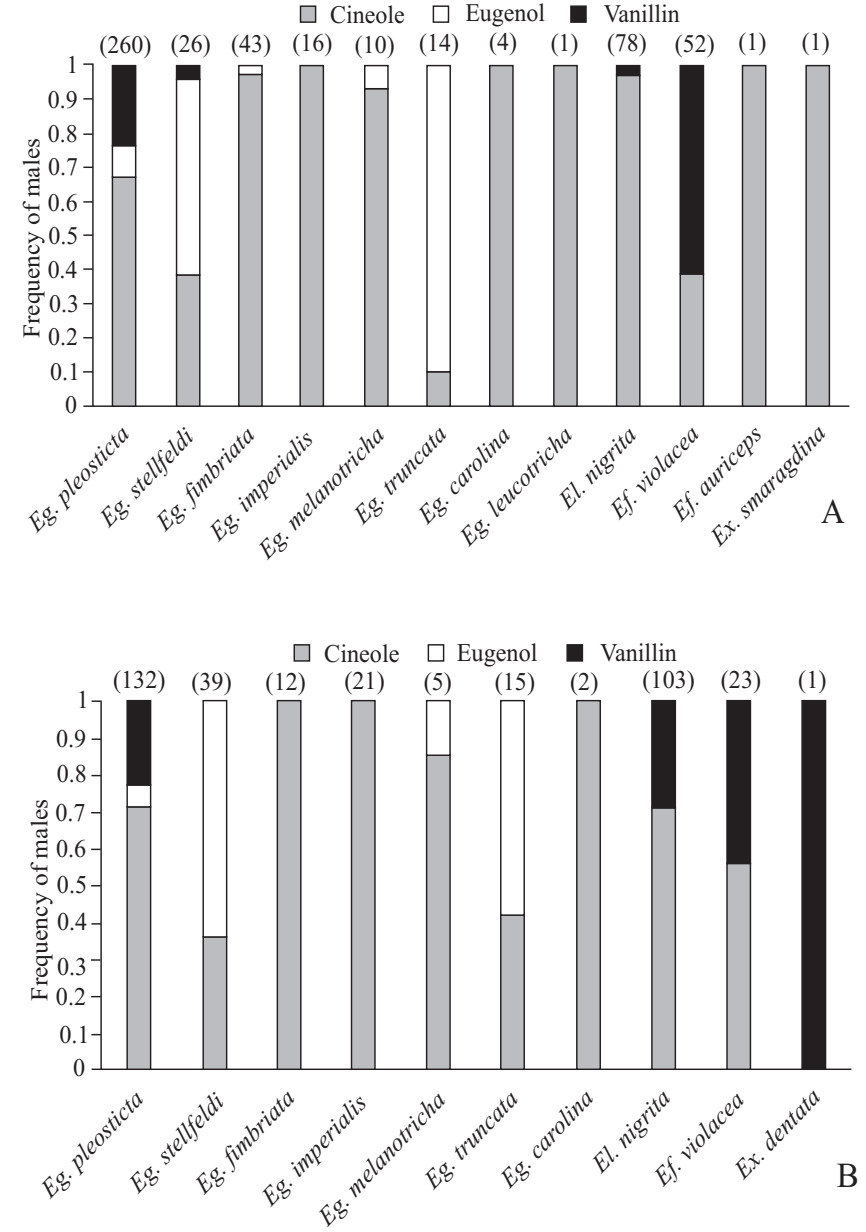

Fig. 3. Frequency of euglossine males captured at each scent bait (cineole, eugenol and vanillin) at sites A (A) and B (B). 
4). However, the fauna was more similar within each site than between sites, irrespective of seasonal differences.

Although there was no significant temperature difference between the two sites $(t=0.50$; d.f. $=20 ; p=0.6)$, bee abundance was more signicantly correlated to temperature at site A (Site A: $r=0.90$; d.f. $=9$; $p<0.001$; Site B: $r=0.69$; d.f. $=9 ; \mathrm{p}=0.01$ ), indicating that this parameter could have influenced the differences in abundance observed between the two sites.

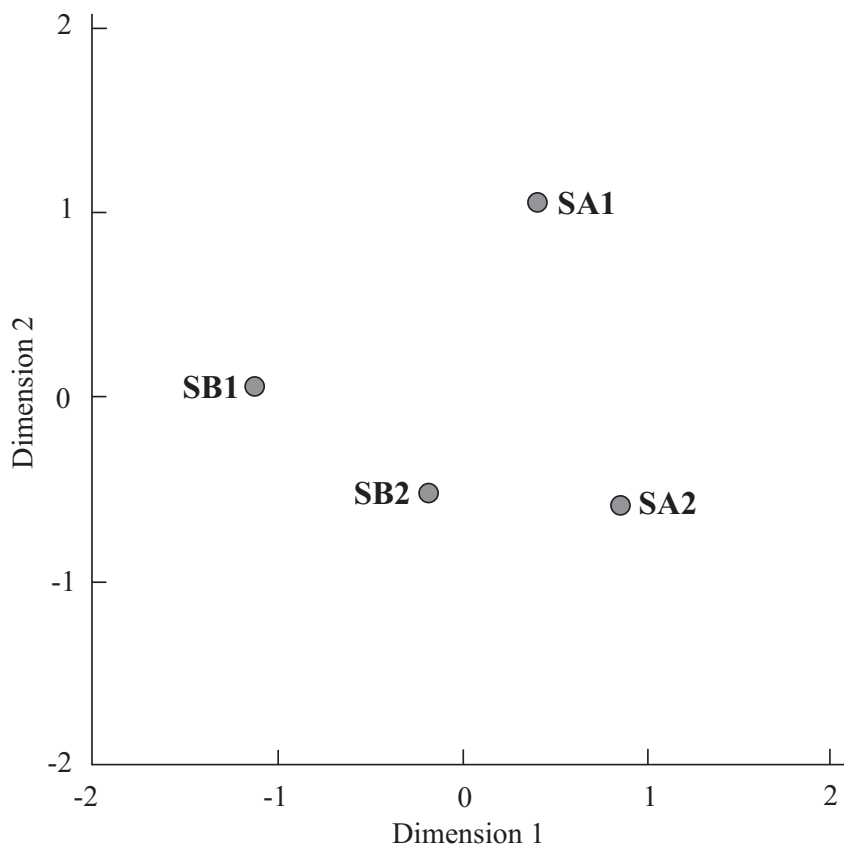

Fig. 4. Similarity between Euglossini fauna from two sampling sites (A and $B$ ) surveyed in the present study during the warm-wet and cold-dry seasons. $\mathrm{SA} 1$ and $\mathrm{SB} 1=$ sites $\mathrm{A}$ and $\mathrm{B}$ during the warm-wet season, respectively; SA2 and SB2 = sites A and B during the cold - dry season, respectively.

\section{DISCUSSION}

The community structure of male orchid bees in the Neotropical region, which was revised in recent years by Nemésio (2007b), shows a pattern with many individuals from a few prevailing species and a large number of species represented by only a few individuals (Janzen et al. 1982; Rebêlo \& Garófalo 1997; Silva \& Rebêlo 2002; Sofia et al. 2004; Aguiar \& Gaglianone 2008; Ramalho et al. 2009). This same pattern was observed in the present study and according to Nemésio (2007b), this pattern represents a general rule for euglossine bee community structure.

The values from species richness estimators and accumulation curves indicated that more species could have been collected. The absence of curve stabilization is a frequently observed result in insect inventory (Gotelli \& Colwell 2001; Brosi et al. 2007). As foragers, bees usually find their resources heterogeneously dispersed throughout their environment (Creswell 2000), which probably results in differences in the distribution of individuals. Despite the desirable low sensitivity of richness estimators to variations in the spatial distribution (Santos 2004), it is possible that a heterogeneous community distribution pattern would influence the curve response. Nevertheless, it is important to point out, particularly in the current study, that although two sampling sites were used, more species could have been collected with increased sampling efforts. Besides, some studies have shown that different Euglossini species can display distinctive pattern of daily activity (Santos \& Sofia 2002; Nemésio 2007b; Melo et al. 2009). Thus, the restrict period of sampling (9-11 h) used in the current study may have interfered on the number of species collected.

A question that has received little attention in studies involving the euglossine community is whether a single sampling site is sufficient to suitably characterize the diversity of local euglossine fauna. In this study, both sampling sites showed a low percentage of euglossine bee similarity and significant differences in abundance. In particular, the variation in composition of species between sites A an B could have be attributed to the sporadic occurrence of some species at each site, such as Exaerete smaragdina (Guérin, 1844) and Exaerete dentata (Linnaeus, 1758), represented by only one individual each in sites A and B, respectively. Additionally, Euglossa leucotricha Rebêlo \& Moure, 1996 and Eufriesea auriceps (Friese, 1899) had just one individual sampled each, and only at site A. However, these differences in species occurrence between sites A and B not necessarily reflect real differences in euglossine fauna between these sites, since only one individual of these four species was collected in one or other site. As previously mentioned (see Material and Methods section) in this study, both sampling sites (A and B) were positioned on the forest remnant border. However, in contrast to site A, site B was situated near the transition between the forest fragment and an area of Cerrado, from which it was separated by only $100 \mathrm{~m}$. Thus, some of the differences found between both sites could have been related to this fact. Whatever the explanation to this finding, in the current study the species accumulation curves and $G$ test results reveal a tendency of more richness and abundance in site A than site B.

Both euglossine richness and abundance can vary over small scale within the habitat (Ambruster 1993). However, divergent findings have also been published elsewhere (Tonhasca et al. 2002b; Nemésio \& Silveira 2006). Although the distribution of resource "hot spots" (e.g., patches of fragrance- or nectar-producing flowers, fragrant fungi etc.) has been pointed out as a possible cause acting in small-scale spatial structuring of male euglossine populations (Armbruster 1993), this author suggests that additional data are needed on within-habitat heterogeneity in male euglossine populations, since these data could help demonstrate, among other things: "how common within-habitat heterogeneity really is, to what extent it occurs and how quantitative among-habitat differences can be compared". 
The composition, abundance and richness of species varied seasonally, as expected for Euglossini bees (Janzen et al. 1982; Ackerman 1983; Rebêlo \& Garófalo 1997). As in other studies, the highest values of species abundance and richness were registered during the hot and humid season (Oliveira \& Campos 1995; Rebêlo \& Garófalo 1997; Sofia et al. 2004). Those values were influenced mainly by variation of dominant species abundance in the area.

Cineole was the most attractive aromatic bait to Euglossini males. Similar results have been found in studies of varying habitat types, such as the Amazonian forest (Powell \& Powell 1987; Becker et al. 1991; Morato et al. 1992; Rebêlo \& Silva 1999), the semideciduous Atlantic Forest (Rebêlo \& Garófalo 1991, 1997; Sofia \& Suzuki 2004) and the Brazilian savannah (Nemésio \& Faria Jr. 2004, Alvarenga et al. 2007). Besides the use of only three fragrances (cineole, eugenol and vanillin) in the present study, 13 species were inventoried in the forest remnant studied (SCF). Rebêlo \& Garófalo (1991, 1997), using the same three fragrances as scent baits, but with a greater sampling effort to survey euglossine fauna in three fragments of Atlantic Forest in northerneastern São Paulo state, found a number and composition of species very similar to SCF. Only three species, Euglossa securigera Dressler, 1982, Euglossa townsendi Cockerell 1904 and Euglossa violaceifrons Rebêlo \& Moure, 1996 (considering that $E$. townsendi and E. violaceifrons were recently considered as Euglossa aratingae Nemésio, 2009 and Euglossa despecta Moure, 1968, respectively, by Nemésio 2009) collected by these authors were not sampled in the fragment that we have analyzed here. However, it is important to emphasize that the use of a larger number of fragrances could provide a better characterization of Euglossini. Regarding collections carried out in a closed biome, for instance, it has been observed that some less-abundant species such as Euglossa decorata Smith and Eg.jacquelynae Nemésio, 2007 which have not attracted by cineole in Cerrado areas (Silveira 2010). The small number of individuals representing some species may be related to either low attraction to the specific fragrances chosen for use or a simple reflection of the structure of the local populations (Rebêlo \& Garófalo 1997).

Eufriesea violacea, a species captured in both sites surveyed in this study, has been classified as a possible area-sensitive species. A recent study by Giangarelli et al. (2009) suggested that Ef. violacea is probably sensitive to fragment size reduction because of its need for larger wooded areas to survive. Eufriesea violacea, as well as other species of this genus, are usually captured in low numbers, never above $5 \%$ of the total number of individuals (Nemésio \& Silveira 2007b). However, in some euglossine studies carried out in semideciduous forests in southern and southeastern Brazil (Garófalo et al. 1998; Jesus \& Garófalo 2000; Sofia \& Suzuki 2004; Sofia et al. 2004) this species has been captured in large numbers. Although SCF is only 49 ha, the very well-preserved condition of this forest remnant could favor the occurrence of $E$. violacea in frequencies corresponding to $10.2 \%$ and $6.5 \%$ of total sample of sites $A$ and $B$, respectively. This study reinforces the need for major efforts to inventory euglossine fauna in remnants of Atlantic Forest.

Finally, the number of Eg. imperialis Cockerell, 1922 sampled in the area was quite higher than that reported by Rebêlo \& Garófalo (1997) in semideciduous forest fragments in southeastern Brazil while using the same baits, indicating structural variation of the euglossine bee community in this region.

Overall, the results of this study supply additional and important information about diversity and distribution patterns of orchid bee fauna in Atlantic Forest remnants and also show that more than one site is sometimes necessary to sample these bees in a fragmented landascape.

\section{ACKNOWLEDGEMENTS}

We are grateful to José Carlos Serrano, FFCLRP- Universidade de São Paulo, for identification of Euglossini species. The manuscript was improved by a number of helpful remarks from two referees.

\section{REFERENCES}

Ackerman, J. D. 1983. Diversity and seasonality of male euglossine bees (Hymenoptera: Apidae) in Central Panama. Ecology 63: 274-283.

Aguiar, W. M. \& M. C. Gaglianone. 2008. Comunidade de abelhas Euglossina (Hymenoptera: Apidae) em remanescentes de Mata Estacional Semidecidual sobre Tabuleiro no Estado do Rio de Janeiro. Neotropical Entomology 37: 118-125.

Alvarenga, P. E. F.; R. F. Freitas \& S. C. Augusto. 2007. Diversidade de Euglossini (Hymenoptera: Apidae) em áreas de cerrado do Triângulo Mineiro, MG. Bioscience Journal 23: 30-37.

Anjos-Silva, E. J. dos \& J. M. M. Rebêlo. 2006. A new species of Exaerete Hoffmannsegg (Hymenoptera: Apidae: Euglossine) from Brazil. Zootaxa 1105: 27-35.

Armbuster, W. S. 1993. Within-habitat heterogeneity in baiting samples of male Euglossine bees: possible causes and implications. Biotropica 25: $122-128$.

Arroyo-Rodríguez, V.; E. Pineda; F. Escobar \& J. Benítez-Malvido 2008. Value of small patches in the conservation of plant-species diversity in highly fragmented rainforest. Conservation Biology 23: 729-739.

Becker, P.; J. S. Moure \& F. Peralta. 1991. More about euglossine bees in Amazoniam forest fagments. Biotropica 23: 586-591.

Bonilla-Gómez, M. A. 1999. Caracterização da estrutura espaço-temporal de comunidades de abelhas euglossinas (Hymenoptera: Apidae) na Hiléia Baiana. Tese de Doutorado. Universidade Estadual de Campinas, 153 p.

Brosi, B. B.; C. D. Gretchen; M. S. Tiffany; O. Federico \& D. Guillermo. 2007. The effects of forest fragmentation on bee communities in tropical countryside. Journal of Applied Ecology 45: 773-783.

Buschini, M. L. T. 2006. Species diversity and community structure in trapnesting bees in Southern Brazil. Apidologie 37: 58-66.

Colwell, R. K. 2006. Estimate S: Statistcal estimation of species richness and shared species from samples. Version 8. Persisten URL Available from http://purl.oclc.org/estimates (accessed 25 February 2009).

Cresswell, J. E. 2000. A comparison of bumblebees' movements in uniform and aggregated distributions of their forage plant. Ecological Entomology 25: $19-25$.

Dodson, C. D.; R. L. Dressler; H. C. Hills; R. M. Adams \& N. H. Williams. 1969. Biologically active compounds in orchid fragrances. Science 164 : 1234-1249.

Garófalo, C. A.; E. Camillo; S.C. Augusto; B.M.V. Jesus \& J.C. Serrano. 1998. Diversidade e Abundância Sazonal de Euglossini (Hymenoptera, Apidae) na Serra do Japi, Jundiaí, SP. Águas de Lindóia. Anais do 
Simpósio de Ecossistemas Brasileiros IV: 72-79.

Gazola, A. L. \& C. A. Garófalo. 2009. Trap-nesting bees (Hymenoptera: Apoidea) in forest fragments of the State of São Paulo, Brazil. Genetics and Molecular Research 8: 607-622.

Gazola, A. L. 2006. Ecologia de abelhas e vespas solitárias (Hymenoptera, Apoidea) que nidificam em ninhos-armadilha em dois fragmentos de floresta estacional semidecidual no Estado de São Paulo. Doctoral thesis, Ribeirão Preto, FFCLRP-USP, 103 p.

Giangarelli, D. C.; G. A. Freiria; O. P. Colatreli; K. M. Suzuki \& S. H. Sofia. 2009. Eufriesea violacea (Blanchard): a euglossine species potentially sensitive to forest patch deterioration in Brazil. Neotropical Entomology 38: 610-615.

Gotelli, N. J. \& R. R. Colwell. 2001. Quantifying biodiversity: procedures and pitfalls in the measurement and comparisions of species richness. Ecology Letters 4: 379-391.

Janzen, D. H.; P. J. Devries; M. L. Higgins \& L. S. Kimsey. 1982. Seasonal and site variation in Costa Rican euglossine bees at chemical baits in lowland deciduous and evergreen forest. Ecology 63: 66-74.

Jesus, B. M. V. \& C. A. Garófalo 2000. Riqueza e abundância sazonal de Euglossini (Hymenoptera, Apidae) na Mata da Virgínia, Matão, São Paulo. Anais do Encontro Sobre Abelhas IV 4: 239-245.

Kruskal, J. B. \& M. Wish. 1978. Multidimensional Scaling. Beverly Hills, Sage Publications, $93 \mathrm{p}$.

Ludwig, J. A. \& J. F. Reynolds. 1988. Statistical Ecology: a Primer on Methods and Computing. New York, John Wiley and Sons Inc., 352 p.

Melo, P. N.; M. Gimenes \& A. Oliveira Neto. 2009. Daily activity patterns of visits by males of four species of Eumaema to odor baits in a tropical forest fragment in Bahia, Brazil. Zoologia 26: 204-212.

Morato, E. F.; L. A. O. Campos \& J. S. Moure. 1992. As abelhas Euglossini (Hymenoptera, Apidae) coletadas na Amazônia Central. Revista Brasileira de Entomologia 36: 767-771.

Nemésio, A. 2003. Preliminary sampling of Euglossina (Hymenoptera: Apidae: Apini) of Reserva Particular do Patrimônio Natural "Feliciano Miguel Abdala", Caratinga, Minas Gerais, southeastern Brazil. Lundiana 4: 121-124.

Nemésio, A. 2006. Euglossa anodorhynchi sp. nov. (Hymenoptera: Apidae), a new orchid bee from Southern Brazil. Neotropical Entomology 35: 206-209.

Nemésio, A. 2007a. Three new species of Euglossa Latreille (Hymenoptera: Apidae) from Brazil. Zootaxa 1547: 21-31.

Nemésio, A. 2007b. The community structure of male orchid bees along the Neotropical Region. Revista Brasileira de Zoociências 9: 151-158.

Nemésio, A. 2009. Orchid bees (Hymenoptera: Apidae) of the Brazilian Atlantic Forest. Zootaxa 2041: 1-242.

Nemésio, A. \& L. R. R. Faria Jr. 2004. First assessment of orchid bee fauna (Hymenoptera: Apidae: Apini: Euglossina) of Parque Estadual do Rio Preto, a cerrado area in southeastern Brazil. Lundiana 5: 113-117.

Nemésio, A. \& E. F. Morato. 2006. The orchid bee fauna (Hymenoptera: Apidae) of Acre state (northwestern Brazil) and a re-evaluation of euglossine bait-trapping. Lundiana 7: 59-64.

Nemésio, A. \& F. A. Silveira. 2006. Edge effects on the orchid-bee fauna (Hymenoptera: Apidae) at a large remnant of Atlantic rain forest in southeastern Brazil. Neotropical Entomology 35: 313-323.

Nemésio, A. \& F. A. Silveira. 2007a. Orchid bee fauna (Hymenoptera: Apidae: Euglossina) of Atlantic Forest fragments inside an urban area in southeastern Brazil. Neotropical Entomology 36: 186-191.

Nemésio, A. \& F. A. Silveira. 2007b. Diversity and distribution of orchid bees (Hymenoptera: Apidae) with a revised checklist of species. Neotropical Entomology 36: 874-888.

Oliveira, M. L. \& L. A. O. Campos. 1995. Abundância, riqueza e diversidade de abelhas Euglossinae (Hymenoptera, Apidae) em florestas contínuas de terra firme da Amazônia Central, Brasil. Revista Brasileira de Zoologia 12: $547-556$.

Parra-H A. \& G. Nates-Parra. 2007. Variación de la comunidad de abejas de las orquídeas (Hymenoptera: Apidae) en tres ambientes perturbados del piedemonte llanero colombiano. Revista de Biología Tropical 55: 931-941.
Peruquetti, R. C.; L. A. O. Campos; C. D. P. Coelho; C. V. M. Abrantes \& L. C. O. Lisboa. 1999. As abelhas Euglossini (Apidae) de áreas de Mata Atlântica: abundância, riqueza e aspectos biológicos. Revista Brasileira de Zoologia 16: 101-118.

Powell, A. H. \& G. V. N. Powell. 1987. Population dynamics of male euglossine bees in Amazonian forest fragments. Biotropica 19: 176-179.

Ramalho A. V.; M. C. Gaglianone \& M. L. Oliveira. 2009. Comunidades de abelhas Euglossina (Hymenoptera, Apidae) em fragmentos de Mata Atlântica no Sudeste do Brasil. Revista Brasileira de Entomologia 53: 95-101.

Ramírez, S. 2005. Euglossa paisa, a new specie of orchid bee from the Colombian Andes (Hymenoptera: Apidae). Zootaxa 1065: 51-60.

Rebêlo, J. M. M. 2001. História Natural das Euglossíneas. As abelhas das orquídeas. São Luís, Lithograf Editora, 152 p.

Rebêlo, J. M. M. \& C. A. Garófalo. 1991. Diversidade e Sazonalidade de machos de Euglossini (Hymenoptera, Apidae) e preferências por iscas-odores em um fragmento de floresta no Sudeste do Brasil. Revista Brasileira de Biologia 51: 787-799.

Rebêlo, J. M. M. \& C. A. Garófalo. 1997. Comunidades de machos de Euglossini (Hymenoptera, Apidae) em matas semidecíduas do Nordeste do estado de São Paulo. Anais da Sociedade Entomológica Brasileira 26: 243-255.

Rebêlo, J. M. M \& F. S. Silva. 1999. Distribuição das abelhas Euglossini (Hymenoptera: Apidae) no Estado do Maranhão, Brasil. Anais da Sociedade Entomológica Brasileira 28: 389-401.

Ribeiro, M. C.; J. P. Metzger; A. C. Martensen; F. J. Ponzoni \& M. M. Hirota. 2009. The Brazilian Atlantic Forest: How much is left, and how is the remaining forest distributed? Implications for conservation. Biological Conservation 142: 1141-1153.

Roubik, D. W. \& P. E. Hanson. 2004. Orchid Bees of Tropical America: Biology and Field guide. Heredia, INBio Press, 370 p.

Santos, A. J. 2004. Estimativas de riqueza em espécies, p.19-41. In: L. Cullen Jr; R. Rudran \& C. Valladares-Padua (orgs.). Métodos de Estudos em Biologia da Conservação e Manejo da Vida Silvestre. Curitiba, Editora UFPR. 667 p.

Santos, A. M. \& S. H. Sofia. 2002. Horário de atividade de machos de Euglossinae (Hymenoptera, Apidae) em um fragmento de floresta semidecídua no Norte do Estado do Paraná. Acta Scientiarum 24:375-381.

Silva, F. S. \& J. M. M. Rebêlo. 2002. Population dynamics of Euglossinae bees (Hymenoptera, Apidae) in an early second-growth forest of Cajual Island, in the state of Maranhão. Brazilian Journal of Biology 62: 15-23.

Silveira, G. C. 2010. Diversidade e sazonalidade de abelhas Euglossini Latreille (Hymenoptera: Apidae) em duas áreas de Mata Estacional Semidecidual no domínio do Cerrado no Triângulo Mineiro. Master Dissertation, Uberlândia, Universidade Federal de Uberlândia, 57 p.

Sofia, S. H. \& K. M. Suzuki. 2004. Comunidades de machos de abelhas Euglossina (Hymenoptera: Apidae) em fragmentos florestais no Sul do Brasil. Neotropical Entomology 33: 693-702.

Sofia, S. H.; A. M. Santos \& C. R. M. Silva. 2004. Euglossine bees (Hymenoptera, Apidae) in an Atlantic Forest remnant in Paraná State, Brazil. Inheringia (Zoologia) 94: 217-222.

Tonhasca Jr., A.; J. L. Blackmer \& G. S. Albuquerque. 2002a. Abundance and diversity of euglossine bees in the fragmented landscape of the Brazilian Atlantic Forest. Biotropica 34: 416-422.

Tonhasca Jr., A.; J. L. Blackmer \& G.S. Albuquerque. 2002b. Within-habitat heterogeneity of euglossine bee populations: a re-evaluation of the evidence. Journal of Tropical Ecology 18: 929-933.

Uehara-Prado, M. \& C. A. Garófalo. 2006. Small-scale elevational variation in the abundance of Eufriesea violacea (Blanchard) (Hymenoptera: Apidae). Neotropical Entomology 35: 446-451.

Wolda, H. 1981. Similarity indices, sample sizes and diversity. Oecologia 50: 296-302.

Received 17/11/2009; accepted 4/1/2011

Editor: Maria Cristina Gaglianone 